\title{
Relative area measurement of maxillary sinus by computed tomography
}

\section{Mensuração da área relativa do seio maxilar por meio da tomografia computadorizada}

Ronaldo Andrade Figueiredo de OLIVEIRA ${ }^{1}$

Maria Cristina PEDRAZINI ${ }^{1}$

Thomaz WASSALL ${ }^{1}$

\section{ABSTRACT}

\section{Objective}

To evaluate the relative area of the maxillary sinus in edentulous posterior maxilla with regard to linear area, bone septa and sinus pathologies.

\section{Methods}

A retrospective longitudinal study was conducted of tomographic exams in 60 individuals between 35 and 75 years of age, with the inclusion criteria being the uni- or bilateral edentulous posterior maxilla. Measurements were taken by the program in 101 maxillary sinuses. The horizontal and vertical measurements of each sinus were multiplied and resulted in a linear area in $\mathrm{mm}^{2}$.

\section{Results}

Of the 101 maxillary sinuses evaluated, 14 presented sinus pathologies (13.86\%) and 22 (21.78\%) with bone septa. The mean mesio distal distance was $38.4 \mathrm{~mm}(p \leq 0.05)$, mean height $34.5 \mathrm{~mm}(p \leq 0.05)$ and mean linear area of $1335.88 \mathrm{~mm}^{2}(p=0.05)$. The Student's-t and analysis of variance (ANOVA) tests were applied for statistical analysis There were no statistically significant difference in the height and width of the edentulous maxillary sinuses between genders, but there was a variation in the linear area and the finding of the presence of bone septa and sinus pathologies.

\section{Conclusion}

The conclusion of this study corroborates those of previous study about the need for imaging exams with the purpose of obtaining information about the dimensions of the maxillary sinus, as guidance with regard to the quantity of graft material, choice of donor region, and presence of septa. These data serve as guidance in the sinus lift technique and the presence of sinus pathologies, which involve treatment before bone graft surgeries.

Indexing terms: Maxillary sinus. Sinusitis. Tomography, X-ray computed.

\section{RESUMO}

Objetivo

Avaliar a área relativa do seio maxilar em maxila desdentada posterior quanto à área linear, presença de septos ósseos e sinusopatias.

\section{Métodos}

Foi realizado um estudo longitudinal retrospectivo de exames tomográficos em 60 indivíduos entre 35 e 75 anos e como critério de inclusão, a maxila posterior desdentada uni ou bilateralmente. As medições foram realizadas pelo programa em 101 seios maxilares. As medidas horizontais e verticais de cada seio foram multiplicadas e resultaram em área linear em $\mathrm{mm}^{2}$.

\section{Resultados}

Dos 101 seios maxilares avaliados, 14 apresentaram sinusopatias (13,86\%) e $22(21,78 \%)$ com septos ósseos. A média mesio distal foi de $38,4 \mathrm{~mm}(p \leq 0,05)$, a altura média de $34,5 \mathrm{~mm}(p \leq 0,05)$ e área linear média de $1335,88 \mathrm{~mm}^{2}(p=0,05)$. Foi aplicado o teste t de Student e análise de variância (ANOVA) para análise estatística. Não houve diferenças estatísticas significantes na altura e largura dos seios maxilares desdentados entre os gêneros, mas houve uma variação da área linear bem como a constatação da presença de septos ósseos e sinusopatias.

\section{Conclusão}

A conclusão deste trabalho corrobora com estudos anteriores sobre a necessidade dos exames por imagem com a finalidade de obter informações quanto as dimensões do seio maxilar norteando a quantidade de material de enxertia bem como a escolha da região doadora, a presença de septos orientando a técnica de levantamento de seio e a presença de sinusopatias que implica em tratamento prévio à cirurgia de enxertos.

Termos de indexação: Seio maxilar. Sinusite. Tomografia computadorizada por raios X.

\footnotetext{
${ }^{1}$ Faculdade São Leopoldo Mandic, Curso de Odontologia, Programa de Pós-Graduação em Implantodontia. Correspondência para / Correspondence to: RAF OLIVEIRA. E-mail: <figueiredooliveira@uol.com,br>.
} 


\section{INTRODUCTION}

The rehabilitation of completely or partially edentulous individuals by means of dental Implants has proved to be a promising resource in Dentistry. However, success depends on a minimum quantity of bone tissue being available for the placement of osseointegratable implants. This minimum bone condition is frequently absent, due to the rapid and continuous process of edentulous alveolar bone resorption, leading to different levels of atrophy. In these cases, reconstruction of the area to be rehabilitated becomes mandatory ${ }^{1-2}$.

Bone reconstruction of the maxillae must be preceded by planning of the case, with information about the medical history of the individual, clinical evaluation of the oral cavity, requisition of imaging exams for analysis of the maxillary sinus volume, presence of septa and/ or sinus infections. This set of information will guide the decision about when and how to perform the surgical reconstruction procedure ${ }^{3-4}$.

Pneumatization of the maxillary sinus with change in volume occurs due to the loss of teeth, and is an indication for performing bone reconstruction by means of bone graft. Depending on this volume, the donor area is selected, and the decision is made about whether or not to use biomaterials associated with autogenous bone ${ }^{5-6}$.

Bone graft in the maxillary sinus was developed from modification of the Caldwell-Luc technique, with full elevation of the whole sinus membrane, in a procedure known as "sinus lift"7-9. The procedure is simple, however, it must be carefully performed, in order to avoid complications such as perforation of the sinus membrane, or post-surgical infections. Internal configurations of the maxillary sinus, such as the presence of bone septa may cause problems limiting osteotomy of the access window through the lateral wall, and facilitate perforation of the sinus membrane ${ }^{10-11}$.

Considering that sinus septa are present in $39 \%$ of maxillary sinuses, and that this fact may cause problems during opening of the lateral window in grafts, the surgeon must always request a computed tomograph before surgery; this is now a consensus ${ }^{12-15}$.

The anatomy of the maxillary sinus may be investigated with the use of panoramic radiographs and/or computed tomographs. Depending on the findings as regards septa, the design of the lateral window must be modified $^{16}$, in order to prevent intercurrences in the procedure.

With regard to sinus pathologies, chronic sinusitis or cysts are factors that must be controlled before the procedure in order to avoid later infection with loss of the graft and/or osseointegration of the implant not occurring ${ }^{17-19}$.

The maxillary sinuses may be affected by pathologies of traumatic origin, neoplasias and particularly by infections arising in the nasal or oral cavities with dental structures and their periodontium. When infection is present in the sinus cavity, it is denominated sinusitis, and this process may obstruct the sinus ostium, making it difficult for the seromucous secretion to leave the sinus cavity. Sinus infections may be of odontogenic origin when they are triggered by bucco sinus fistulas, endodontic or periodontal infections, by the presence of dental cysts or tumors. Non odontogenic sinus infections may arise from anatomic obstructive nasal conditions, such as deviation of the nasal septum and alterations in the position and size of the sinus ostium, concha bullosaand/or hypertrophic bulbous projection, due to allergic conditions, which may also cause hypertrophy of the adenoids and nasal mucosa ${ }^{20}$.

In view of the problem studied, the aim of this study was to perform an analysis of the area relative to the maxillary sinuses; that is, the height and width of the sinus cavity, by means of Computed Tomography NewTom 3G® ${ }^{\circledR}$ (Mod.

QR-DVT9000-QRSRLTM, Verona, Italy) with volumetric acquisition and $3 \mathrm{D}$ reconstruction specifically of three aspects: difference in linear measurements between genders; presence of bone septa, and diagnosis of sinus pathologies, in order to equate the possible obstacles existent to performing the bone graft techniques, such as anatomical, pathological and linear variations.

\section{METHODS}

The research was approved by the Research Ethics Committee of the School of Dentistry, São Leopoldo Mandic, Protocol No. 07/148 and the retrospective longitudinal study was conducted by means of a survey of the documents in the archives of the Dental Radiology Institute - IRO (Instituto Radiológico Odontológico - IRO) in Campinas (SP), Brazil.

An evaluation was made of 60 pre-operative computed tomographs to record the linear measurements and extension of pneumatization of the maxillary sinus, presence or absence of sinus pathologies and bone septa in individuals of the male and female genders between 35 and 75 years of age. The inclusion criteria were: completely, uni- or bilaterally edentulous posterior maxillae, and in conditions to be submitted to bone graft surgery with maxillary sinus lift and later rehabilitation with dental implants. 
The computed tomographs were performed with the Cone Beam Computed Tomograph - NewTom 3G® (Mod. QR-DVT9000-QRSRLTM, Verona, Italy) with low exposure to radiation and high resolution results. The operating parameters were $110 \mathrm{KVp}$ and variable MAs (calculated by the size of the individual), $1 \mathrm{~mm}$ thick cuts, acquisition time 36 seconds and cone beam opening of 9 inches (removal of image).

To obtain the computed tomographs, the individual was placed lying on his/her back, and the image of the maxilla was obtained with the individual's head placed in the Reid's Base Line position (Orbital-Meatal line) perpendicular to the work table and median sagittal plane parallel to it.

From the computed tomography images with the panoramic cut chosen in the most central region of the arch, the quantitative linear evaluation of the maxillary sinus was obtained by two lines: one vertical $(V)$ and the other horizontal $(\mathrm{H})$. The vertical line was dimensioned from the lowest point of the sinus floor to its highest point, at the margin of the orbital floor and the horizontal line demarcated at the largest mesio distal extension of the sinus cavity; that is, from the medial limit wall with the nasal cavity up to the distal wall next to the tuberosity of the maxilla (Figure 1).

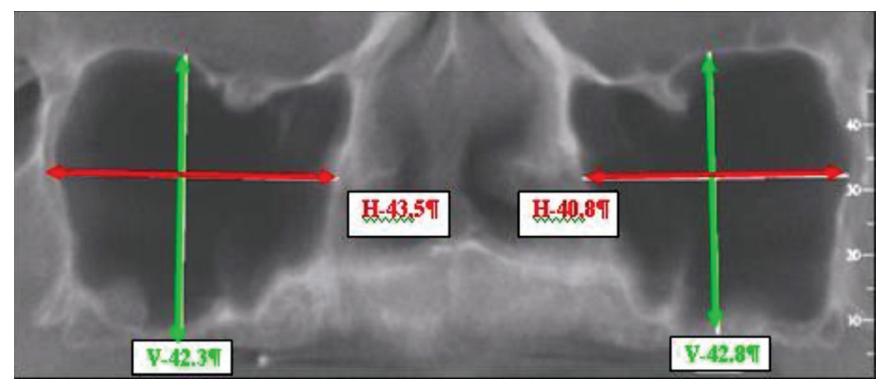

Figure 1. Demonstration of computed tomographs and acquisition of linear measurements of a bilaterally edentulous individual ( $\mathrm{V}$ - vertical; $\mathrm{H}$ horizontal)

The vertical and horizontal measurements were taken with the software program of the tomograph itself (QRNNT version 2.02) and were multiplied to obtain an area in square millimeters denominated S1 or S2 (area/ $\left.\mathrm{mm}^{2}\right)=\mathrm{V}(\mathrm{mm}) \times \mathrm{H}(\mathrm{mm})$, with $\mathrm{S} 1$ being - area of the right or left maxillary sinus (unilaterally edentulous) or of the right maxillary sinus (bilaterally edentulous) and S2 - area of the left maxillary sinus (bilaterally edentulous).

The presence of sinus pathologies such as thickening of the mucosa, retention cysts and opacification or radiolucency of the sinus cavity were evaluated by a single examiner using one single negatoscope apparatus (Figure 2).

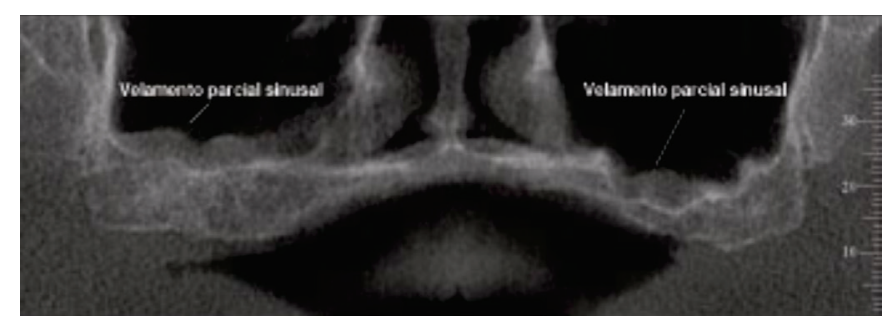

Figure 2. Computed tomography with presence of sinus pathology (Example: partial sinus concealment).

With regard to bone septa, these were scored by evaluating their presence in the maxillary sinus floor by panoramic reconstruction of the computed tomographs, and confirmed in longitudinal cuts (Figure 3).

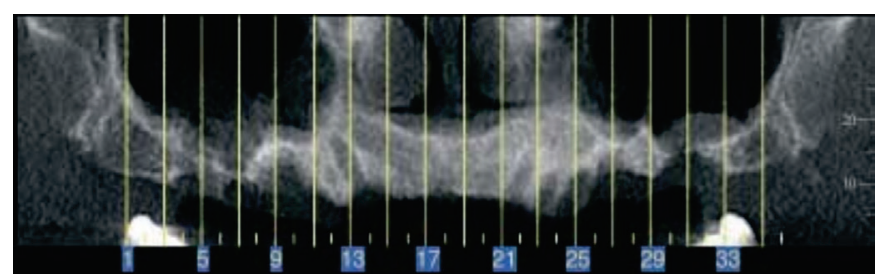

Figure 3. Computed tomograph with presence of bone septa highlighted.

Analysis of Variance (ANOVA) and Student's- $t$ tests were applied to the evaluations of the linear measurements and areas of the sinuses using the SAS statistical software program with a $5 \%$ level of significance.

The differences in height, width and areas obtained in the measurements of the sinuses were compared by dividing the groups by gender, and by the unilateral or bilateral presence of edentulous area.

\section{RESULTS}

Of the 24 individuals of the male gender, 8 were unilaterally and 16 bilaterally edentulous, totaling 40 maxillary sinuses. Eight presented sinus pathologies and 15 bone septa. Of the 36 individuals of the female gender, 11 were unilaterally and 25 bilaterally edentulous, totaling 61 maxillary sinuses. Six presented sinus pathologies and 7 bone septa.

Of the total of 101 maxillary sinuses analyzed, $14(13.86 \%)$ sinuses presented sinus pathologies and 22 (21.78\%) bone septa.

As regards sinus height and width, the mean value between genders was $38.4 \mathrm{~mm}$ in width and $34.52 \mathrm{~mm}$ in height. As regards the relative area of the sinuses, the mean observed in the male gender was $1367.53 \mathrm{~mm}^{2}$ and in the female gender it was $1315.13 \mathrm{~mm}^{2}$. The total mean relative area of the edentulous maxillary sinuses was $1335.88 \mathrm{~mm}^{2}$. 
Mean height and width values of each gender considering the location of the edentulous sinus were submitted to Analysis of Variance (ANOVA) and were shown to differ between them by $p \leq 0.05$.

Analysis of Variance of the areas (S1) did not differ between them with $p>0.05$. The areas (S2) submitted to the Student's- $t$ test considering gender and the edentulous maxillary sinus, did not differ between them with $p>0.05$.

\section{DISCUSSION}

As success in Implant Dentistry may only be achieved if a meticulous study has been performed, all the alternatives diagnosed must be used in order to know the areas that will be operated, or submitted to graft procedures, or only to the placement of implants. Evaluation of the bone margins may be performed, in addition to clinical exam, by means of intraoral radiographs, panoramic radiographs, computed tomography and magnetic resonance (MR), with the use of computed tomography being a reliable and safe alternative for this type of evaluation.

Cone Beam technology, in addition to providing quality images, provides data about the quantity of remaining bone, anatomic structures involved and the characteristics of possible donor regions ${ }^{21}$. It minimizes the time of patient exposure during the procedure, diminishes artifacts that make it difficult to interpret the images, and enables the capture of 30 or more cuts with a thickness of 0.5 and $1 \mathrm{~mm}$. Furthermore, tomography is the only means of observing the bone thicknesses available during the selection of the size and type of implant ${ }^{22-23}$.

In view of these affirmations, the use of computed tomography is recommendable both in complex and routine cases, due to its capacity to reconstruct a complete tridimensional model of the maxilla and mandible, with precise definition of the structure of the maxilla and anatomic location of critical structures ${ }^{24}$.

In view of this diagnostic alternative, there is no justification for an intervention in the maxillary sinus performed "in the dark". Detailed knowledge about the morphology of this maxillary region is clinically relevant in order to reduce complications when sinus lift surgery is performed ${ }^{25-26}$.

The sinus cavity is complex, and may be divided by bone septa which are cortical bone folds invaginated into the sinus. These septa may be complete ( 1 to $10 \%$ ) or incomplete, and this condition may be visualized in imaging exams.
Septa are present in 13 to $35.3 \%$ of maxillary sinuses ${ }^{27}$, numbers that are in agreement with those found in this study, in which $22 \%$ of sinuses with the presence of septa were observed.

The size of the septum may range from 2.5 to $23.7 \mathrm{~mm}$ in mean length, and there are reports of a higher prevalence of septa in atrophic than in non atrophic edentulous areas. Maxillary sinus lift in the presence of a septum requires a modification in the design of the lateral window, in order to prevent intercurrences in the procedure ${ }^{16}$, and the success rate of sinus floor lift is clearly related to the presence of bone septa ${ }^{15}$.

Another fact that must be observed in maxillary sinuses is the presence of absence of infectious pathologies that generate serious complications. These pathologies, denominated sinusitis, may be acute or chronic and must be diagnosed from the individual's history and clinical and radiographic exams. The symptoms are not specific and resemble those of a common cold or allergic rhinitis. The cause of sinusitis is bacterial inhalation associated with edema of the mucosa lining the sinus, which makes it difficult for drainage of the secretion to occur, and facilitates bacterial colonization. The individual's history associated with acute sinusitis includes unilateral headache and pain in the area of the maxilla. The teeth, even when they are vital, may be painful and sensitive. Chronic sinusitis presents headache, edema of the face and thick purulent hypersecretion, generally with a yellowish or greenish color.

The maxillary sinuses may be affected by pathologies of traumatic, neoplastic and infectious origin. The infectious types are more frequent due to the proximity of the nasal cavity and dental and periodontal structures of the maxilla. Because of this proximity, these infections may be classified as being of odontogenic origin (10\% of cases with minimal clinical symptoms) and non odontogenic, such as acute or chronic sinusitis. Sinus infections may be of odontogenic origin are generally unilateral, and are triggered by buco sinus fistulas, endodontic or periodontal infections, and also by the presence of dental cysts or tumors. The non odontogenic type may be uni- or bilateral and arise from obstructive nasal conditions, such as deviation of the nasal septum, concha bullosa and/or hypertrophic concha, hypertrophy of the adenoids and nasal mucosa, alteration in the position and size of the sinus ostium, and allergic diseases such as sinusitis may cause obstruction of the ostium. Traumatisms resulting from the Caldwell-Luc techniques sometimes obstruct the main ostium, leading to an accumulation of secretion inside the cavity and its consequent expansion, accompanied by expansion of the adjacent bone tissue. This phenomenon 
denominated mucocele is more common in the paranasal and frontal sinuses, and rare in the maxillary and sphenoid sinuses. Non secretory or pseudocysts originate from the accumulation of inflammatory exudates below the periosteum, resulting from sinus infections; whereas retention or secretory cysts originate from obstruction of the duct of a seromucous gland; that is to say, because of the non drainage of the secretion, the duct and gland dilate giving rise to a cystic structure ${ }^{20}$.

Irrespective of the cause of the sinus pathology, which in this study presented in $14 \%$ of the sinuses investigated, it should be diagnosed and treated before any invasive procedure is performed.

With regard to sinus topography - very important in the study of the surgical technique to be used and calculation of the bone volume to be grafted researchers ${ }^{1,27}$ have analyzed the topographical anatomy during surgeries as well as radiographically, and found mean heights of $3.5 \mathrm{~cm}$, widths of $2.5 \mathrm{~cm}$ and depths of $3.0 \mathrm{~cm}$ in sinuses, which corroborate the results with reference to height and mesio distal extension found in the present study. The dimensions of the maxillary sinuses are variable and depend on factors such as age, gender, ethnicity, and individual conditions, quite often varying when one side is compared with the other in the same individual. In adults, the size remains stationary in normal condition, however, after permanent tooth extractions, the size of maxillary sinuses increases by the occupation of root spaces. This pneumatization may be greater after

\section{REFERENCES}

1. Brånemark PI. Introduction a la osscointegracion. In: Brånemark PI, Zarb GA, Albrektsson T. Protesis tejido integradas: la osscointegracion en la odontologia clínica. Barcelona: Quintessence Books; 1987. p. 11-75.

2. van Steenberghe $D$, Lekholm $U$, Bolender C, Folmer T, Henry P, Herrmann I, et al. Applicability of osseointegrated oral implants in the rehabilitation of partial edentulism: a prospective multicenter study on 558 fixtures. Int J Oral Maxillofac Implants. 1990;5(3):272-81.

3. Misch CE. Implantes dentários contemporâneos. $2^{\text {a }}$ ed. São Paulo: Editora Santos; 2000. p. 469-95.

4. Whaites E. Princípios de radiologia odontológica $3^{a}$ ed. Porto Alegre: Artmed; 2003.

5. Fernandes CL. Volumetric analysis of maxillary sinuses of Zulu and European crania by helical, multislice computed tomography. J Laryngol Otol. 2004;118(11):877-81. extraction of all the maxillary teeth, or when partial a extractions occur in the first decades of life.

With this increase in sinus volume, tomographic exams help to define the quantity of bone graft to be requested for sinus lift and later implant placement. A12 $\mathrm{mm}$ increase in height requires $1.7 \pm 0.9 \mathrm{cc}$; and for 17 $\mathrm{mm}$ the volume required is $3.6 \pm 1.5 \mathrm{cc}$, therefore, this knowledge of the receptor area is essential for making decisions on the choice of donor area; extension of the surgical intervention, and even deciding about the type of graft material to be used, because depending on the extension of the receptor area, it may be necessary to complement the graft with the use of biomaterials ${ }^{6}$.

\section{CONCLUSION}

The study about the relative analysis of the maxillary sinus allowed one to conclude that detailed preoperative evaluation of the maxillary sinus is important and there is consensus in the literature about this affirmation.

With the use of computed tomography it is possible to calculate the quantity of material to be grafted in the sinus, thereby diminishing the morbidity of the patient operated, with regard to donor areas. Finding the presence of septa and/or sinus pathologies guides the dental surgeon with regard to the best procedure to adopt for the prevention of problems, so that the intervention, and the best time for the surgery may be planned.

6. Krennnmair $G$, Krainhöfner $M$, Maier $H$, Weinländer $M$ Piehslinger E. Computerized tomography-assisted calculation of sinus augmentation volume. Int. J. Oral Maxillofac Implants. 2006;21(6):907-13

7. Boyne PJ, James RA. Grafting of the maxillary sinus floor with autogenous marrow and bone. J Oral Surg. 1980;38(8):613-6.

8. Tatum Junior H. Maxillary and sinus implants reconstructions. Dent Clin North Am. 1986;30(2):207-29.

9. Kent JN, Block MS. Simultaneous maxillary sinus floor bone grafting and placement of hydroxyapatite-coated implants. J Oral Maxil.lofac Surg. 1989;47(3):238-42. doi: 10.1016/02782391(89)90225-5.

10. Velásquez-Plata D, Hovey LR, Peach CC, Alder ME. Maxillary sinus septa: a 3-dimensional computerized tomographic scan analysis. Int J Oral Maxillofac Implants. 2002;17(6):854-60.

11. Magini RS. Enxerto ósseo no seio maxilar. São Paulo: Editora Santos; 2006. 
12. Ella B, Noble RC, Lauverjat $Y$, Sédarat C, Zwetyenga N, Siberchicot $F$, et al. Septa within the sinus: effect on elevation of the sinus floor. Br J Oral Maxillofac Surg. 2008;46(6):464-7. doi: doi: 10.1016/j.bjoms.2008.01.016.

13. Naitoh M, Suenga $Y$, Kondo S, Gotoh K, Ariji E. Assessment of maxillary sinus septa using cone-beam computed tomography: etiological consideration. Clin Implant Dent Relat Res. 2009;11(Suppl1):e52-8. doi: 10.1111/j.17088208.2009.00194.x.

14. Koymen RA, Gocmen-Mas NB, Karacayli UA, Ortakoglu KA, Ozen TC, Yazici ACD. Anatomic evaluation of maxillary sinus septa: surgery and radiology. Clin Anat. 2009;22(5):563-70. doi: 10.1002/ca.20813.

15. Neugebauer J, Ritter L, Mischkowski RA, Dreiseidler T, Scherer $P$, Ketterle $M$, et al. Evaluation of maxillary sinus anatomy by cone-beam CT Prior to sinus floor elevation. Int J Oral Maxillofac Implants. 2010;25(2):258-65.

16. Maestre-Ferrín LA, Galán-Gil SA, Rubio-Serrano MA, Peñarrocha-Diago MB, Peñarrocha-Oltra DA. Maxillary sinus septa: a systematic review. Med Oral, Patol Oral Cir Bucal. 2010;15(2):383-6.

17. Maksoud MA. Complicações após o aumento do seio maxilar: relato de caso. J Implant Dent. 2003;1:74-6.

18. Timmenga NM, Raghoebar GM, van Weissenbruch R, Vissink A. Maxillary sinus floor elevation surgery: a clinical, radiographic and endoscopic evaluation. Clin Oral Implants Res. 2003;14(3):3228. doi: 10.1034/j.1600-0501.2003.140310.x.

19. Schwartz-Arad D, Herzberg R, Dolev E. The prevalence of surgical complications of the sinus graft procedure and their impact on implant survival. J Periodontol. 2004;75(4):511-6. oi:10.1902/ jop.2004.75.4.511.

20. Nary Filho $H$, Padovan LEM. Fixação zigomática: uma alternativa para reabilitação em maxilas atróficas. São Paulo: Editora Santos; 2008.

21. Garg AK. Augmentation grafting of he maxillary sinus for placement of dental implants: anatomy, physiology, and procedures. Implant Dent. 1999;8(1):36-46.
22. Tyndall DA, Brooks SL. Selection criteria for dental implant site imaging: a position paper of the American Academy of Oral and Maxillofacial radiology. Oral Surg Oral Med Oral Pathol Oral Radiol Endod. 2000;89(5):630-7. doi: 10.1067/ moe.2000.106336.

23. Chilvaquer I. Radiologia na implantodontia osseointegrada. In: Freitas A, Rosa JE, Souza IF. Radiologia odontológica. $5^{a}$ ed. São Paulo: Artes Médicas; 2000.

24. Garg AK. Dental implant imaging: TeraRecon's dental 3D cone beam computed tomography system. Dent Implantol Update. 2007;18(6):41-5.

25. Krennmair G, Ulm C, Lugmayr H. Maxillary sinus septa: incidence, morphology and clinical implications. J Craniomaxillofac Surg. 1997:25(5):261-5.

26. Rosano G, Taschirei S, Gaudy JF, Weinstein T, Del Fabrro M, Maxillary Sinusvascular Anatomy and its relation to sinus lift surgery. Clin Oral Implants Res. 2011;22(7):711-5. doi: 10.1111/j.1600-0501.2010.02045.x.

27. Di Nardo MIT, Capelozza ALA, Costa NP. Seios maxilares. JBC J Bras Odontol Clin. 1998;2(9):39-44.

28. Uchida Y, Goto M, Katsuki T, Akiyoshi T. A cadaveric study of maxillary sinus size as an aid bone grafting of the maxillary sinus floor. J Oral Maxillofac Surg. 1998;56(10):1158-63. doi: 10.1016/S0278-2391(98)90761-3.

29. Tasoulis G, Yao SG, Fine JB. The maxillary sinus: challenges and treatments for implant plaement. Compend Contin Educ Dent. 2011,32(1):10-4. 